\title{
Firms in developing countries
} \section{A theoretical probe into the borderland of Business Studies and Development Studies}

\author{
Hansen, Michael W.; Schaumburg-Müller, Henrik
}

Document Version

Final published version

Publication date:

2007

License

CC BY-NC-ND

Citation for published version (APA):

Hansen, M. W., \& Schaumburg-Müller, H. (2007). Firms in developing countries: $A$ theoretical probe into the borderland of Business Studies and Development Studies. Centre for Business and Development Studies. CBDS Working Paper Vol. 2007 No. 5

Link to publication in CBS Research Portal

\section{General rights}

Copyright and moral rights for the publications made accessible in the public portal are retained by the authors and/or other copyright owners and it is a condition of accessing publications that users recognise and abide by the legal requirements associated with these rights.

\section{Take down policy}

If you believe that this document breaches copyright please contact us (research.lib@cbs.dk) providing details, and we will remove access to the work immediately and investigate your claim. 

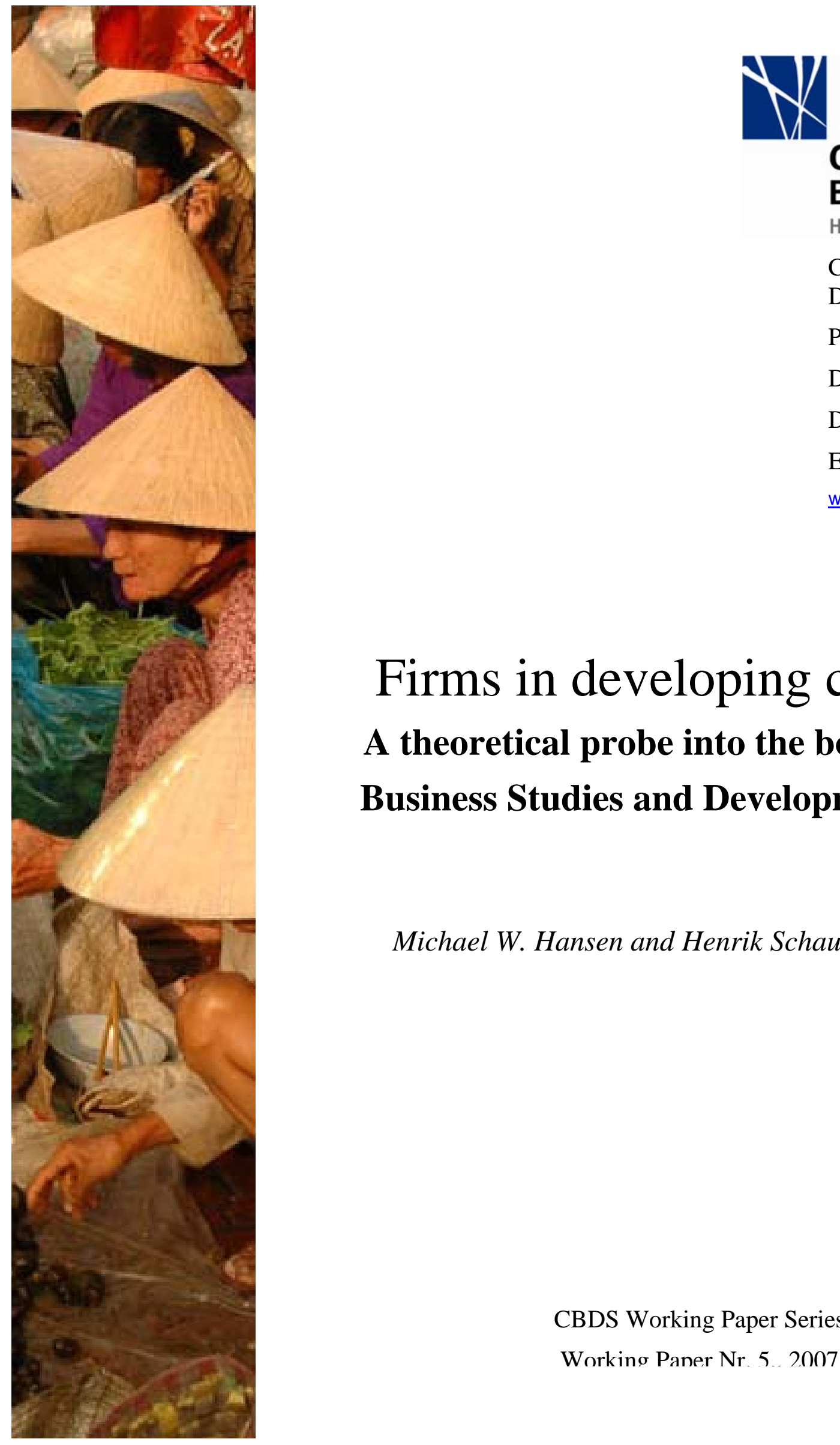

Copenhagen Business School HANDELSHØJSKOLEN

Centre for Business and Development Studies

Porcelænshaven 18

DK-2000 Frederiksberg Denmark

Email: cbds@cbs.dk www.cbs.dk/cbds

\title{
Firms in developing countries
}

\section{A theoretical probe into the borderland of Business Studies and Development Studies}

\author{
Michael W. Hansen and Henrik Schaumburg-Müller
}

CBDS Working Paper Series

Working Paner Nr. 5.. 2007 


\title{
Firms in developing countries
}

\author{
A theoretical probe into the borderland of Business Studies and Development Studies ${ }^{1}$ \\ Michael W. Hansen \& Henrik Schaumburg-Müller \\ CBDS, Copenhagen Business School
}

\begin{abstract}
Business studies and development studies have evolved relatively independently of each other - business studies occupied with profit maximizing strategies and the activities of entrepreneurs, firms and value chains, and development studies with economic, social and political development strategies of countries and regions. However, as more and more of the world's value-adding activities take place in developing countries and as MNCs increasingly incorporate developing countries' markets and resources in their strategies, business studies has taken a growing interest in the particular conditions of local and foreign firms doing business in such environments. Simultaneously, as the limitations of state led development strategies have become apparent and as market ideology has become prevalent in a growing number of countries, development studies has directed growing attention towards the role of entrepreneurship, firm strategy, private sector development and foreign direct investment as vehicles for economic and social development. In other words, both fields approach business in development from different sides. This paper seeks to identify themes related to the firm in developing countries as taken up by both business and development studies. We suggest the themes of common interest and potential convergence to be those of market failures, institutions, entrepreneurship, clusters, and firm internationalization. The paper illustrates that there are substantial opportunities for cross-fertilization between the two bodies of academic enquiry, and indeed, that without a conversation between the two literatures in the era of globalization, the analytical and predictive power of both may be seriously impaired.
\end{abstract}

Keywords: development studies, business studies, theories of international business, multinational corporations, clusters and developing countries

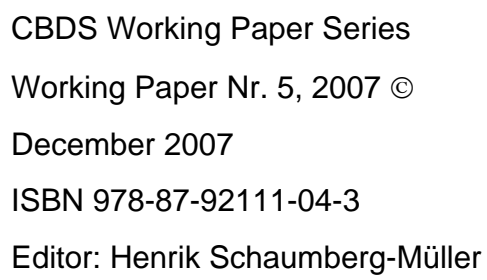

\footnotetext{
${ }^{1}$ We would like to thank Peter Wad for valuable input in regard to the sections on the sociology of science. Thanks also to Eugene Pottenger for dedicated research assistance and editing.
} 


\section{Firms in developing countries}

\section{Introduction}

Business activity in developing countries is attracting increasing attention from both business and development studies. Within business studies, more and more attention is being devoted to local and foreign-owned firms in developing countries and the conditions of doing business in such countries. Meanwhile, within development studies, growing attention is being devoted to the role of entrepreneurs, firms and markets in facilitating economic and social development. Yet, in spite of the growing interest in firms in developing countries by both business and development studies, it appears that the two literatures have evolved more or less separately in terms of the main questions, dominant theories and preferred methodologies. In particular, there appears to have been limited cross-fertilization or mutual inspiration, and we will argue that the two literatures could each benefit greatly from a closer scrutiny of the developments and insights of the other. In this paper we thus attempt to identify overlapping themes and common interests with a view towards the creation of an agenda for business and development studies. We start out by discussing what business studies and development studies are about, as well as what their main differences and similarities are in terms of thematic interest and methodological approach. We then move on to review the theoretical contributions of both fields across a number of themes related to the firm in developing countries where we believe there is evidence of, or potential for, dialogue and mutual inspiration.

\section{Characterizing business studies and development studies}

Before we move on to identifying issues of mutual interest, let us briefly explain what we mean by business studies and development studies.

We cannot say that development studies and business studies are disciplines, as disciplines require consensus on both an object of application and appropriate methodologies, as well as limited reliance on imports from other disciplines (Foss, 1996; 4). Business studies and development studies bring together a host of disciplines, including economics, sociology, psychology, anthropology, political science, geography, etc., each with their own methodologies and key questions. Thus, the term 'field' (Foss, 1996) is probably a more appropriate characterization for both business studies and development studies.

Fields of academic enquiry can be more or less integrated. Whitley characterizes academic fields ${ }^{2}$ on two dimensions: one, the extent to which researchers are 'dependent' on each other to make competent knowledge claims, and two, the degree to which researchers face 'task

\footnotetext{
${ }^{2}$ Fields are what Whitley (1984) labels 'reputational work organizations'. They have their own criteria through which contributions are selected and rewarded. The ideal such organization manages to balance the need for innovation and the generation of new theories and methodologies with the ability to select among these (Foss, 1996).
} 
uncertainty', namely uncertainty regarding which questions to address and which methodologies to adopt. Among the generic types of fields, at one extreme is the 'partioned bureaucracy' which is characterized by clear criteria for selection among knowledge claims and low problem and method ambiguity. At the other extreme is the 'fragmented adhocracy' which is characterized by unclear hierarchy in regard to knowledge claims and uncertainty as to key problems and methods. From Whitley's typology, it is not difficult to argue that both development studies and business studies are 'fragmented adhocracies' ${ }^{3}$. Fields may move toward greater integration or greater fragmentation and Foss $(1996$; 6) points out that fragmented adhocracies can easily stay fragmented, especially when they are highly problem oriented, as is the case with development studies and business studies. The reason is that in a problem oriented field, research is strongly driven by the emergence of new empirical problems and this tends to jeopardize processes of theoretical and methodological convergence.

In spite of the clearly fragmented and adhocratic nature of both fields, we believe that it is meaningful, and indeed useful, to delineate each one. In our view, what unites business studies and development studies is the fact that both fields share a common thematic core as well as common assumptions in their literature as to the purpose of research ${ }^{4}$.

\section{a. Business Studies}

Business studies encompasses a number of subfields, including strategy, organization, and management, and draws on a large number of disciplines, including economics, sociology, psychology, political science, and anthropology, among others. The thematic core is the understanding and study of the survival and growth of the firm. Thus, central issues of interest include such questions as: 'What are organizations?', 'What is managerial practice?' and 'What are the strategies that best position firms for survival and growth?' Moreover, business studies is typically micro-oriented in the sense that the unit of analysis is the firm, the manager, or the entrepreneur. While macro (e.g. country) and meso (e.g. industry) conditions are of course included in research and analysis within the field, they are typically treated as exogenous influences on firm strategy. As to causality and change, agency plays a significant role in business studies as strategizing is essentially viewed as choice in the face of external constraints (Minzberg, 1988). Finally, business studies is a highly problem oriented and normative field; researchers typically train and advise (or are themselves) managers and thus questions of how to improve efficiency and performance are always at the heart of training, teaching and analysis.

\section{b. Development Studies}

Development studies is essentially about understanding the conditions and paths of development with a view towards facilitating and promoting development. The subject area of development studies is the "societal reproduction and transformation processes of the developing countries, in conjunction with the international factors that influence these

\footnotetext{
${ }^{3}$ Foss (1996; 8) explicitly characterizes business studies as a fragmented adhocracy.

${ }^{4}$ Indeed, most researchers within the two fields would be able and/or willing to clearly identify themselves with either one.
} 
processes" (Martinussen, 1999; 4). A basic hypothesis embedded in development studies is that developing countries are different from other categories of countries and that additional tools, theories and methodologies are needed to fully comprehend such contexts and thus provide a sound basis for prescriptions ${ }^{5}$ (Martinusen, 1999). Development studies is also a highly normative field in the sense that change, namely development, is the core thematic interest. Research is frequently practical and action oriented and researchers in the field are themselves typically strongly involved in development work. Generally, development studies takes a systemic approach to development in the sense that development is seen as a characteristic of an agglomeration of agents (a country, a region, a segment), and only rarely that of individuals or individual organizations. Moreover, agents have traditionally been seen as carriers of structural dimensions and dynamics restricting agency (Pieterse, 2001) although agency has recently become a key concept in the poverty literature. Historically, development studies has moved from a focus on Marxist or liberal grand development theories (e.g. Prebisch's dependency theory or the modernization theories proposed by, among others, Rosenstein-Rhodan and

\begin{tabular}{|l|l|l|}
\hline & Business studies & Development studies \\
\hline $\begin{array}{l}\text { Main } \\
\text { focus }\end{array}$ & $\begin{array}{l}\text { The survival and growth of } \\
\text { the firm. }\end{array}$ & $\begin{array}{l}\text { The conditions and paths of } \\
\text { development }\end{array}$ \\
\hline $\begin{array}{l}\text { Unit of } \\
\text { analysis }\end{array}$ & $\begin{array}{l}\text { Micro level analysis (Firm, the } \\
\text { manager, or the } \\
\text { entrepreneur) }\end{array}$ & $\begin{array}{l}\text { Macro and meso level analysis } \\
\text { (Region, country, group, industry, } \\
\text { sector) }\end{array}$ \\
\hline $\begin{array}{l}\text { Structure } \\
\text { and } \\
\text { agency }\end{array}$ & $\begin{array}{l}\text { Strategizing is essentially is } \\
\text { about choice in the face of } \\
\text { external constraints }\end{array}$ & $\begin{array}{l}\text { Structural bias of development } \\
\text { studies }\end{array}$ \\
\hline $\begin{array}{l}\text { Normative } \\
\text { orientation }\end{array}$ & $\begin{array}{l}\text { Research is practically and } \\
\text { action oriented }\end{array}$ & $\begin{array}{l}\text { Research is practically and action } \\
\text { oriented }\end{array}$ \\
\hline
\end{tabular}

Rostow) toward meso-level theories (e.g. industrialization strategy theory) and thematic theories (e.g. environment and sustainable development, women, etc.) (Martinussen, 1999; 7). Micro-level theories, which earlier were employed in studies of peasant farmers in developing countries (Bates, 1988), have recently come to play a greater role in development studies, for example in the study of households, bureaucrats, firms, and entrepreneurs. It is, inter alia, as part of this movement in development studies toward micro-level theories that we find opportunities for including insights from business studies in the development studies discourse.

\section{c. The need for greater integration of the two fields}

Thus, we have two huge fields of academic enquiry, one focused mostly on macro and meso issues of economic growth, poverty alleviation and industrialization, and another on microeconomic issues of firm survival, growth and competitiveness. One field has a strong structural orientation, while the other assigns preeminence to agency within structural constraints. We contend that neither has taken appropriate notice of the other, partly due to the fundamental differences in focus and mission, and partly due to a historically determined division of the appropriate journals to publish in, conferences to attend, and criteria for

\footnotetext{
${ }^{5}$ The neoclassical counter argument is that the only thing developing countries have in common is development assistance: "The Third World is the creation of foreign aid; without foreign aid there is no Third World" (Bauer, 1981; 87 as cited in Martinussen 1999; 9).
} 


\section{A theoretical probe into the borderland of Business Studies and Development Studies}

evaluating contributions ${ }^{6}$. Yet we believe that each field stands to benefit significantly from increased cross-fertilization and exchange. In particular, business studies needs a better understanding of the specificities of developing countries. In the words of one prominent business scholar: "For strategy research in this area to flourish and make a lasting contribution there is a need to consider the extent to which theories and methodologies used to study strategy in mature, developed economies are suited to the unique social, political, and economic contexts as well as firm characteristics of emerging economies" (Wright et al. 2005; 2). Meanwhile, development studies needs to complement its traditional focus on macro and meso variables with an understanding of the micro-economic dynamics of firms and organizations. In the words of Teece (2000; 105), "despite the centrality of the business firm to economic growth and economic development, development economics has given relatively short shrift to the firm as an agent of economic development. . . . The weight of the literature focuses on the role of macro economic variables and the public sector in the development process ... [and] the poor state of the development economics literature is possibly due to the relative neglect of the study of firms and the institutions that support firms".

Furthermore, we argue that a number of developments related to economic globalization make it increasingly pertinent for the two fields to engage in a conversation. First, development studies increasingly needs the insights of business studies as the outward oriented and FDIbased development strategies largely being adopted in the developing world make it essential to understand the interface between MNC strategy and economic development. Relevant issues thus include, among others, an understanding of which types of foreign investors create more significant direct and spillover effects for host countries, and which MNC strategies are more likely to produce broad local linkages rather than foster enclave economies. Second, business studies increasingly needs the insights offered by development studies. In particular, the immense market and resource potentials of emerging economies (such as China and India), as unleashed by globalization, make it critical for managers and analysts to have a deeper understanding of the risks and opportunities of such locations. Thus, there is a need to develop tools to understand the particularities of these markets as well as the institutions which surround them (Peng, 2002; Wright et al., 2005; Meyer and Peng, 2005). As noted by Hoskissson et al. (1999; 445), "there is no theoretical work, nor empirical findings suggesting that the existing body of knowledge (on strategy, ed.), largely obtained in the context of United States, is equally applicable in other countries"

\footnotetext{
${ }^{6}$ While it is our impression that interaction between the two fields is currently taking place, it is worth noting that a number of authors have actually consistently straddled the two fields. Among the 'trespassers' are economists such as Hirshman, Lall and Schumpeter, who have ventured on to explore the role of firms and entrepreneurs in economic development, and business economists such as Hymer, Dunning and, more recently, Prahalad, who have ventured into development thinking from a business strategic point of view.

${ }^{7}$ Peng too doubts that traditional IB theory is directly transferable to emerging markets and calls for theory development: "The rapidly moving events of the global environment, such as the rise of emerging economies as the new IB battleground (Hoskisson et al., 2000; Peng, 2003) and the impact of antiglobalization activities on IB (Buckley and Ghauri, 2004; Doh and Teegen, 2003; Eden and Lenway, 2001), necessitate innovative theoretical perspectives and empirical methodologies to provide new answers to this question and modify old answers (Dunning, 2000)”.
} 


\section{Firms in developing countries}

What we are proposing is not to look for, or develop, a hybrid field of business and development studies, but rather to search for areas of conversation and mutual inspiration ${ }^{8}$. In particular, we strongly believe that more interaction will spark intellectual innovation for both fields. For such exchange and inspiration to take place, there needs to be mutual recognition and understanding of basic concepts and methodologies (Foss, 1996). Simply put, protagonists of the two fields need to be able to talk to each other in a similar language. Thus, this paper will present a mainly economic account of the two fields' dealings with firms in developing countries in the hope that an economic perspective will make it easier to illustrate the potential of cross-fertilization ${ }^{9} 10$.

\section{d. Themes of actual or potential convergence of interest}

The method we propose is to identify some emerging themes related to the firm in developing countries where both fields are devoting growing attention and see if there is an actual or potential basis for co-reading and mutual inspiration ${ }^{11}$. A large number of themes where business studies and development studies are, or may be converging in terms of focus could be taken up; however in this paper we will emphasize four broadly defined areas where we see actual or potential convergence of interest.

1. Markets and institutions: Two generic themes cut through both business and development studies, namely markets and institutions. In understanding these two phenomena, we argue that business and development studies have actually moved significantly toward each other in recent years. Markets and deviations from efficient markets are of central interest to both business and development studies, and institutions have come to the fore in the literature on firm strategy in developing countries as well as the development strategy literature.

2. Entrepreneurship: Historically, a key interest of both development and business studies has been the firm's origin and development, and this in turn has raised issues of entrepreneurship,

\footnotetext{
${ }^{8}$ According to Kanbur (2002), there are different ways to combine disciplines. One is to "go for deep integration right from the beginning and to keep that going right through the analysis, all the way to policy recommendation”. This Kanbur labels ‘interdisciplinary’. Another approach is multidisciplinary, suggesting “to let each discipline do its best in its own terms and using its own methods in the first place, and then to use the results from each discipline to develop an overall analytical synthesis and policy conclusions” (Kanbur, 2002; 483).

${ }^{9}$ When we emphasize the economic approach within both fields, it is mainly to make the comparison manageable. Thus, we do not argue that other disciplines - for example, sociology, political science, anthropology, geography, etc. - are less important or less worthy representatives of the two fields. At a later stage, the logic employed in this paper could be extended to include these other disciplines.

${ }^{10}$ It has been argued that too much pluralism in terms of theory and methodology can be a problem and that stronger economic rigor is often needed. In particular, a field needs norms for conversation between participants in order to evolve. Several authors suggest that the infusion of economics may assist in this process (Foss, 1996; 9).

${ }^{11}$ As argued by Kanbur (2002; 484) in his review of development economics vis-a-vis other disciplines within development studies, the way to achieve greater cross-referencing between disciplines "is to advance through the analysis of concrete issues and problems ... demonstrating how two disciplines are better than one. Let each discipline do its best and learn from the other in an atmosphere of openness and respect, and see how the conclusions of each line of enquiry, specifically targeted to a well defined and focused problem, can be synthesized in the policy context”.
} 


\section{A theoretical probe into the borderland of Business Studies and Development Studies}

small and medium-sized enterprise growth, learning, and innovation. The issue of entrepreneurship in developing countries has recently regained prominence in both fields and is an area where we find significant opportunities for the integration of the two perspectives.

3. Clusters and networks: Clusters and networks have been discussed intensively within both fields. In this paper we will examine clusters and networks partly as a means by which individual firms can benefit from cooperation with other firms by exploiting the division of labor and accessing knowledge to promote learning and improve competitiveness, and partly as a way for countries to promote economic development in economies with no flagship firms.

4. Firm internationalization: Finally, with global trade and investment liberalization, the issue of firm internationalization has come to the fore in both business and development studies. We will look at this issue from three angels, namely with respect to developing country firms, global value chains, and MNCs.

In what follows, we examine these four themes separately, first to see how business studies and development studies have each addressed them individually, and then to identify areas of actual or potential convergence of interest.

\section{Markets and institutions}

Markets and institutions are two fundamental organizational forms that are at the core of both business and development studies. The two are highly interdependent - markets can be seen as a special form of institution and institutions provide the underpinnings for the functioning of markets. Moreover, institutional factors are frequently a source of market failure.

\section{a. Markets and market failures}

One of the main issues of concern for economists is when markets succeed in delivering efficiency and when they fail. Market failure theory is an effective heuristic device to explain empirical occurrences of market failure in relation to an ideal situation of the perfect allocation and utilization of resources. Market failure is a key concept both in development and business studies. However, while development studies looks to market failures to explain why markets sometimes fail to produce welfare gains, business studies uses market failures to explain why firms exist and succeed.

\section{Development studies}

In development studies, market failures/imperfections are typically seen as welfare reducing and therefore as impeding development. Information imperfections lead to in-optimal consumption $^{12}$, limit entrepreneurship (Rodrik, 2004), cause the misallocation of resources

\footnotetext{
${ }^{12}$ A classic case is that of the Indian milk market in the 1960s. This market collapsed as consumers lost confidence in the quality of the product. By introducing a labelling and control system, the state restored the confidence of consumers and the market again flourished (Lynn, 2002).
} 


\section{Firms in developing countries}

(Bates, 1988), prevent financial resources from reaching good projects ${ }^{13}$ and result in other negative outcomes. The existence of externalities leads to welfare loss from market exchange, for example with respect to pollution. Imperfections in political markets, such as prisoner dilemma dynamics and the possibility of free-riding, lead to collective action problems so that certain desirable activities are not organized (e.g. the production of public goods). Structural market failures, such as those associated with oligopolistic industries, cause reductions in consumer welfare and inhibit the development of an effective private sector. At the same time, it should be noted that market imperfections need not always be welfare reducing. In recent years, some economists have directed attention to positive externalities from market exchange, or so called spillovers (for reviews, see Blomstrøm and Kokko, 2000; Meyer, 2004). According to this view, benefits from market transactions can reach firms and organizations not part of the transaction due to competition, demonstration or agglomeration effects.

One of the debates surrounding market failures is whether they are more prevalent and/or more severe in developing, as opposed to advanced, economies. On the one hand, it is argued that in the least developed countries, many markets, especially those for intermediary goods (capital, technology labor), are exceptionally inefficient, if not non-existent (Rugman, 1981). Similarly, it is argued that the potential for positive spillovers is larger in developing countries due to the greater span in technology between foreign and local firms (Giroud and ScottKennel, 2006). On the other hand, it is also argued that market failures become increasingly prevalent as economies become knowledge and innovation driven as opposed to factor and investment driven (Dunning, 1997; Porter, 2003).

Deviations from perfect markets provide ample rationale for development intervention (Lall, 2000). Thus, governments must mitigate information imperfections (e.g. by making trustworthy information freely available), ensure that externalities are addressed (e.g. via taxes and/or subsidies), and curb monopolies (e.g. through regulation). While most mainstream economists would agree that market failures justify market intervention, some economists have argued that market failures in developing countries are of a more fundamental nature than those of more 'normal' economies. Thus, according to the so called Structuralist School, fundamental inefficiencies in the allocation of resources both internally within developing countries and externally between countries warrant strong government intervention. This school of thought thus prescribes massive state intervention in the allocation of resources and activist, hands-on industrialization policies (Prebish, 1950). Countering this argument, neoclassical economists have long maintained that even if there was a theoretical basis for massive intervention in the market to address structural imbalances in a developing economy, it would often still be advisable to forego such intervention, as the potential impact of government failure (e.g. rent seeking, self-dealing and other misaligned

\footnotetext{
${ }^{13}$ According to Stiglitz (1998), "market failure is a fundamental cause of poverty, and financial market failures, which mainly arise from market imperfections, asymmetric information and the high fixed costs of small-scale lending, limit the access of the poor to formal finance, thus pushing the poor to the informal financial sector or to the extreme case of financial exclusion".
} 


\section{A theoretical probe into the borderland of Business Studies and Development Studies}

incentives) may be much worse than that of any market failure, it set out to cure (Bhagwati, 1982; Bhagwati and Srinivasan, 1999).

\section{Business studies}

In business studies, market failures play equally as important a role as within development studies. Essentially, market failures explain why firms exist (Coase, 1937; Williamson, 1975), or in other words, they explain the 'make' or 'buy' decisions of firms. Thus, the existence of market imperfections, and in particular transaction costs, can under certain conditions make it too costly to conduct transactions in the market and these transactions are therefore internalized within the firm. The nature of the product/technology (e.g. its tacitness and/or intangibility) paired with the nature of the market (e.g. the degree of opportunism and the asset-specificity of the transaction) influence which activities firms choose to internalize.

\section{Issues of convergence}

Large firms, MNCs and welfare: The literature on firms in developing countries has traditionally conceived of the market power of large firms, such as conglomerates or MNCs, as potentially welfare reducing (Hymer, 1976). This view has been questioned from two sides. First, it is argued by transaction cost economics that large firms of the market-failurecircumventing-type benefit welfare as they organize economic activity that would not otherwise have been organized due to prohibitively high transaction costs. In particular, large firms can often mitigate risk and compensate for market-failure in capital, labor and product markets through a variety of mechanisms, including cross-subsidies and internal knowledge sharing (Khanna and Palepu, 1997), risk diversification (Khanna and Palepu, 1997) and international technology and knowledge transfer (Buckley and Casson, 1976; Kogutt and Zander, 1992). Secondly, it has been argued that at least a temporary suspension of competition is necessary in order for innovation to take place. The innovator must have a relatively realistic expectation of a secure market for a certain period after commercializing the invention if he is to assume the risks of innovation (Blomstrøm and Kokko, 2000; Rodrik, 2004). In sum, we find that the issue of the welfare and development effects of large firms offers interesting new opportunities for research.

The application of management thinking to development strategy: Managerial thinking appears to be invading development agencies and government bureaucracies in developing countries (Pieterse, 2001??), inspiring new types of development intervention (or at least, new ways of presenting development intervention). In a provocative essay on the roles of governments and MNCs, John Dunning goes so far as to argue that in the era of globalization governments have a lot to learn from large MNCs. MNCs are used to dealing with the paradoxes of markets and hierarchies, competition and cooperation, efficiency and equity, and globalization and localization, and these are many of the same paradoxes that now increasingly confront governments around the world (Dunning, 1997). 


\section{Firms in developing countries}

\section{b. Institutions}

Market failures frequently emanate from the nature of the institutions that surround particular markets ${ }^{14}$. In recent decades, this insight has fueled a literature that seeks to understand the institutional sources of market failures and imperfections. In the context of this paper, the point is that the institutional environment in developing countries has moved to the fore of research in both development studies and business studies.

\section{Development studies}

One of the seminal events in the recent evolution of development studies has been the 'discovery' of institutions. Authors such as Stiglitz and North have argued that a key condition for economic growth and development is the existence of appropriate institutions ${ }^{15}$ (North, 1990; Stiglitz, 2003). In connection with IMF and World Bank Structural Adjustment Programs, it was realized that the liberalization of economies both internally and externally does not automatically produce economic growth, let alone development. The answer offered by the New Institutionalist School was that appropriate institutions are a key prerequisite for markets to work. Thus, markets are shaped by non-economic institutions, including both the formal, such as a judiciary, and the informal, such as the basis for trust in exchange relationships. Proponents of this perspective argue that institutions are of first order importance: it is better to have the wrong policy in the right institutional environment than the right policy in the wrong institutional environment (Rodrik 2004; 18).

The insights of the institutional perspective are reflected in several streams of literature that directly or indirectly deal with economic development. For instance, the competitiveness literature (e.g. Porter, 1990) analyzes the microeconomic foundations of competitiveness and points out that governments play a key role in facilitating the various facets of country competitiveness. The institutional underpinnings of economic development also play a key role in related literatures on innovation systems (e.g. Lundwal, 1998) and learning systems (e.g. Viotti, 2002). One of the key areas where the significance of the institutionalist position has been particularly evident is in the industrialization-strategy literature. Proponents argue that industrialization-strategy is essentially about countering market forces, as market forces left to themselves will not produce adequate development (Rodrik, 2004). One classic industrialization strategy has been to protect domestic industries with an aim of developing a home market for light manufacturing that can then lead to the development of the capacity to produce capital goods. This is the so called import substitution industrialization (ISI) strategy. The philosophy behind this strategy is that industries in developing countries are at an 'infant'

\footnotetext{
14 Transaction cost economics ascribes transaction costs partly to uncertainty. Two types of uncertainties are typically cited, namely 'behavioral' and 'environmental' (Brouthers and Nakos, 2004). Behavioral uncertainties are associated with the level of opportunism in the market, whereas environmental uncertainties are associated with the host country, for example in the protection of property rights, contract enforcement and regulation (ibid, 233-234). It is in this sense that the institutional and transaction cost perspectives are closely related.

${ }^{15}$ According to one observer "Institutions are rules, enforcement mechanisms and organizations...... Institutions are the rules by which agents interact and the organizations that implements rules and codes of conduct” (World Bank, 2002). Rules can be formal (e.g. written rules, laws, organizations under the law) or they can be informal institutions (e.g. norms, social networks, culture, etc).
} 
stage and therefore need protection until they have evolved to the point where they can fend for themselves. Another strategy has been to protect and support domestic industries with a view towards promoting exports, or the so called export promotion industrialization (EOI) strategy. In this regard, it has been debated whether the outstanding economic growth of the East Asian tigers in the post-war period is attributable to the opening of internal markets, as argued by the World Bank (World Bank, 1993), or rather due to 'clever' state intervention that promoted an export orientation in certain industries while protecting others against international competition (Evans, 2006; Weiss, 1998). The latter view holds that it has been institutions rather than markets that explain the Asian miracle, institutions created by an 'embedded' but 'autonomous' bureaucracy ${ }^{16}$.

\section{Business studies}

Seen from a business perspective, institutions such as firms exist due to failures of the market. Thus, the new institutionalism provides a key insight into the existence and growth of the firm (Coase, 1937; Williamson, 1975). But institutions have also informed business studies in another more direct way, and in particular it has been argued that the underlying institutions are critical to understanding business strategy in developing countries (Peng 2002; Wright, 2005; Meyer, 2004). Thus, "treating institutions as independent variables, an institution based view on business strategy (therefore) focuses on the dynamic interaction between institutions and organizations and considers strategic choices as the outcome of such interaction" (Peng, 2002:253). As one example, "a firm in the west has relatively clear legal boundaries characterized by hierarchical control by top management [while] a firm ... in many Asian economies tends to have blurring boundaries permeated by personal connections, partial ownerships and board interlocks" (ibid). Overall, according to Khanna and Palepu (1997; 41), emerging markets "fall short to varying degrees in providing the institutions necessary to support basic business operations". Therefore, specific types of strategies are required in such locations.

Although, it is unclear how this perspective is fundamentally different from the transaction cost perspective discussed above ${ }^{17}$, the focus on the institutional underpinnings of business strategy has provided a valuable tool for analyzing firm strategy in country contexts that are radically different from 'normal' (read 'western') markets.

The institutional perspective on strategy has received attention in the literature on firm management and strategy for quite some time. The Journal of Management Studies had its special issue on strategy research in emerging economies in 2005, in which Mike Wright and

\footnotetext{
16 'Embedded autonomy' is essentially about regulators remaining autonomous from rent seeking private interests while engaging in dialogue with private interests to elicit useful information (Rodrik, 2004).

${ }^{17}$ While institutions are responsible for creating or mitigating many of the transaction costs in local markets, not all transaction costs necessarily arise from institution failure (search costs, uncertainty and opportunism, asset specificity, etc.). However, institutions may determine in large part how these transaction costs are dealt with. Beyond that, institutions can have a much broader impact on such things as business systems, organizational structure, etc., as well as overall development.
} 


\section{Firms in developing countries}

his colleagues further developed the special considerations necessary for emerging markets based on transaction cost theory, resource based theory and institutional theory (Wright et al., 2005). In the same issue of the journal, Narayanan and Fahey take issue with Porter's strategies, as based on his Five Forces Framework, and their application to the institutional contexts of emerging economies. Two of their findings are particularly relevant to our argument: (1) the norms for firm rivalry and their implications for competitive dynamics are not well documented, and (2) network type strategies need research that uncovers the source of effectiveness of the different strategies found in different economies (Narayanan and Fahey 2005:218). Strategic management research has a long history in Asia, and in the special issue of the Asia Pacific Journal of Management on Asian management research, its frontiers and its challenges, Chuong-Ming Lau (2002) draws attention to the fact that the contributors call for the development and valuation of new constructs, designs and methodologies to deal with the context and institutions of developing countries and emerging markets. In a following issue of the same journal, Steven White provides an extensive review of Asian management research, critically assessing questions, methodologies and contributions from 840 articles. Here as well, a core argument seems to be that Asian management research has not been able to impact on and contribute to management research in general (White, 2002). So far, the overriding interest of the strategic management literature on firms in developing countries has been related to the implications for firm strategy of institutional deviations from the standard Anglo-Saxon institutional setting.

\section{Issues of convergences}

Thus, it is evident that the same phenomena - institutions - are being 'endogenized' in both business thinking and development thinking. What then are the areas of actual or potential convergence of interest for the two fields?

Private sector development: In recent years, private sector development has become a key development strategy in both developing countries and among donor agencies (Altenburg \& von Drachenfels, 2006). To us, it appears that the literature on private sector development tends to be too focused on institutions, and too little concerned with understanding what is going on inside the developing country firm. In order to be effective, such private sector institutions need a deep understanding of the functioning of firms. In other words, there is a need for an understanding of how firms react strategically to the different institutional environments provided by regulators and donor organizations and a need for donor agencies to understand how institutions impact the functioning of firms in these developing countries.

Embedded autonomy: The notion of embedded autonomy as developed by Wade, Evans and others, can serve as inspiration for both development studies and business studies. The key is that embedded autonomy is a two-way process where regulators engage with industry in order to better understand the workings of the industry and market, while firms simultaneously engage in learning from regulators. In particular, we will argue that the firm-side of the embedded autonomy equation needs further elaboration: when do firms see a strategic interest in engaging in such close dialogue with regulators, and what are the forces preventing the regulator-business relationship from degenerating into capture?

\section{Entrepreneurship and small and medium sized enterprises}

Business and development studies have a common interest in what sparks change. Neoclassical economic theory does not offer much to explain why capitalist firms change routines and grow. Here, Joseph Schumpeter's development theory laid a foundation for understanding 


\section{A theoretical probe into the borderland of Business Studies and Development Studies}

economic development and the firm in capitalist economies. Within development studies, Schumpeter's work also formed the point of departure for a long tradition for exploring the phenomena of entrepreneurship, innovation and technological change, which on the policy side gave birth to an ongoing interest in the development of small-scale enterprises. Schumpeter's contribution has had a continuous impact on both streams of thinking and has been an important inspiration for the inclusion of issues of the firm in development studies.

The conceptualization of the role of entrepreneurship was formulated by Joseph Schumpeter in his analysis of economic growth and development contained in the Theory of Economic Development, first published in German in 1911 (Schumpeter, 1955). This was a macroeconomic growth model in which the role of the entrepreneur was integrated as the microeconomic foundation of the theory. In his model, overall economic growth was dependent on the supply of entrepreneurial resources, which in turn depended on the independent variables of the rate of profit in society and its social climate. For Schumpeter, the entrepreneur was the man who sees, explores and exploits new opportunities. Technical change and innovation are closely associated with the theory because it is the entrepreneur who transforms innovations into business propositions and growth. Schumpeter's theory can be seen as an alternative way of understanding the development of the capitalist system - alternative to that of both market based Neo-classical economics and Marxist economics - with the theory's relationship between social/institutional context and the supply of entrepreneurial resources from an actorbased perspective. Schumpeter's conception of entrepreneurship is an example of a concept arising within development studies, then being fully integrated into business studies in order to understand the origin of the firm and its growth.

\section{a. Business studies}

Schumpeter's focus on the microeconomic foundations of growth was incorporated into the business literature as a core element for understanding the firm from an entrepreneurial perspective. This approach developed into a strong tradition of knitting entrepreneurship, innovation and the theory of the firm together, and the resulting rich literature was further developed into a neo-Schumpeterian theory of the firm (Winter, 1964). The neoSchumpeterian literature, sometimes called the resource-based perspective of the firm, takes up issues of routine and innovative behavior and the conceptualization of complex organizations and tasks (Winter, 2006). This literature is obviously highly relevant for the understanding of firms and managers in developing countries, but, in practice, it is relatively theoretically oriented with few explicit references to the developing country firm. One can only observe that the term 'entrepreneurship' in its Schumpeterian understanding is used (and often abused) in relation to developing countries and emerging markets, with no clear distinction being made between what are mere routine tasks, what is learning and adaptation and what constitutes innovation as it is taking place in the activities performed by the developing country firms.

The Schumpeterian debate on entrepreneurship and firm growth has also unfolded in the literature on small and medium size enterprises (SMEs) and their capabilities for passive or active learning as part of their growth processes (Caves, 1998; Hall, 1987; Jovanovic, 1982), as well as the importance of size for recovering innovation investments (Klepper, 1996). However, these discussions are based on empirical material from SMEs in developed countries.

The strategy literature has only gradually included developing countries and emerging economies in relation to entrepreneurship. In their search for theories relevant to transition economies, Meyer and Peng (2005) have investigated the three basic lines of theorizing: (1) organizational economics theory, (2) resource-based theories, and (3) institutional theories. 


\section{Firms in developing countries}

They conclude that applying these theories in their standardized form to transition economies raises a number of puzzles and questions about the underlying assumptions (ibid). Some of these issues have been dealt with above in our discussion of markets and institutions, but Meyer and Peng make the important empirical distinction with respect to firms operating in transition economies between what they call local incumbent firms - meaning mainly larger and primarily state owned and privatized enterprises, new private entrepreneurial firms, and foreign entrant firms. This categorization is equally relevant for the industrial organization of most developing countries. Such a categorization also brings in the size dimension of firms in developing countries. In particular, development studies seems to have a biased focus on SMEs, while business studies more persistently analyzes the development of large firms and conglomerates (Khanna and Palepu, 2000).

\section{b. Development studies}

In development studies, entrepreneurship reemerges in the context of industrialization and the role that particularly SMEs can play in this process. This interest arises mainly at the policy level out of the belief that emerging economies have few large private enterprises that can drive the industrialization process, or that large enterprises are not given priority for political reasons. Thus, fostering entrepreneurship for the development of SMEs becomes the central policy concern for an SME-based industrialization strategy.

However, the above mentioned business literature has also had a spillover on the development literature where the issues of firm growth and survival are taken up based now on empirical evidence from developing countries (Liedholm and Mead, 1999). However, some of the basic findings from developed economies - that firm survival tends to grow with size and age, but their growth rate tends to become lower when the firm grows larger and older - seem to hold for SMEs in developing countries as well. Liedholm's empirical work, primarily in Africa, is a key reference to firm based-data and sets standards for many following studies of SMEs also outside Africa. But many studies are concerned with the possibilities of supporting the development of SMEs and the debate on policy options for SME-led industrial development.

Another important tradition, although with fewer contributions and perhaps with less policy relevance, more directly follows the Neo-Schumpeterian view of looking inside the developing country firm to understand its contribution to growth and development. We have already in the introduction cited Teece for pointing out the importance of understanding how accumulation of knowledge, creation of capabilities and assets, and various ways of accessing technology take place in developing country firms (Teece 2000). At the meso- and macrolevels a very rich body of studies has been made with a focus on industrial organization and national innovation systems also in developing countries (Hamilton, 1991; Nelson, 1993; Lundvall, 1998; Rasiah 1999) ${ }^{18}$.

\footnotetext{
${ }^{18}$ A rich literature on these subjects related to both developed and developing countries has been initiated by activities of the DRUID Group.
} 


\section{A theoretical probe into the borderland of Business Studies and Development Studies}

\section{c. Issues of convergence}

The most obvious field in which business and development studies have merged together is in the field of entrepreneurship and SMEs. Here a tradition has been sustained of using common approaches and tools for the studies - independent of whether the location was developed or developing countries. A number of common specialized international journals publishing SME research is the manifest proof of this, including theme issues publishing studies across the developed and developing country divide (Iqbal and Urata 2002) ${ }^{19}$.

\section{Clusters and networks}

\section{a. Industrial clusters - a common heritage}

There are limitations to what firms and particularly small firms are able to do on their own. But they can benefit from being located together with other firms. Already by the end of the $19^{\text {th }}$ century, the thought of benefits from agglomeration was strongly put forward by Alfred Marshall in his "Principles of Economics". The agglomeration benefits for the firm arise primarily from a vertical division of labor that makes better use of capital investments and creates possibilities for flexible specialization, from spillovers when firms having similar production activities learn from each other creating an innovative and competitive firm environment, and, finally, from the marketing benefits of being at the same location as its competitors making it clear to the customer where to source the product. These benefits from inter-firm relations nurrished Marshall's concept of "external economies” or synergies created from inter-firm cooperation outside anonymous markets. This can be seen in a market failure perspective, where firms facing high transaction costs in the market need not internalize activities but can lower transaction costs and obtain benefits from externalities through their locations close to other firms.

Business as well as development studies have drawn on the common heritage of Alfred Marshall's industrial clusters and agglomeration although in different ways in the sense that the two stream of literatures have taken somewhat diverse directions but both maintained a high degree of relevance for normative recommendations not so much at the firm strategy level but more on a meso-level and not least at a national policy level. However, as we shall see there has also over the past three decades been a tendency of convergence on issues of agglomeration and clusters.

With the academic heritage going back to Marshall, clusters have since then received renewed interest from both development and business studies. Development studies has focused on the impact of clusters on industrial development to formulate meso-level policy recommendations designed to capture the perceived benefits of clusters, while business studies has largely

\footnotetext{
19 E.g. International Small Business Journal (see eg. 21:1 pp. 73-91); Small Business Economics (see special issue 18; 2002 pp. 1-12)
} 


\section{Firms in developing countries}

focused on the implications of clusters for investment, firm-level strategy, and competitiveness at firm, regional and national levels.

\section{b. Business studies}

We are by no means in a position to claim that business studies' interest for industrial clusters and agglomeration lowered after Alfred Marshall's contributions, but it was not that part of his work that subsequently came to inspire development economics, when his work lead the way to formulating the body of neo-classical economic theory. However, it appears right to say that the understanding of inter-firm relations and the possible benefits that could arise from proximity are not the most pronounced aspects of understanding the firm in neo-classical theory.

Making a jump in time we can see that the interest for inter-firm relations and agglomeration arise from empirical observations at the national and regional level when trying to answer the question why certain regions or nations among industrial countries develop faster with an apparent concentration of firms in the same or related industries? They develop fast in the sense that they have higher production and income growth than neighboring regions. We will argue that there two streams of literature growing out of this concern, related but nevertheless with different focuses. They may not be considered only as business studies because they are also very much concerned with regional development and national competitiveness and thereby contain a strong element of policy analysis and recommendations.

By the mid 1970s a transformation of industrial organization took place in many industrialized economies creating smaller and more flexible production units and an increased use of subcontracting. This can be seen as a reaction to the trend of internalization because of market failures but not resulting in an increased use of the market. Maintaining control of core ownership advantages, firms can create relations of cooperation and build trust with other firms while at the same time lowering their transaction costs. In business studies the tendency became accommodated in firm network theories (Johanson and Mattson). Empirically, the agglomeration dimension was added. In Europe it was initially developments in North and Middle Italy and Baden-Würtenberg in Germany, and in the US it was for example the Silicon Valley that caught the attention. Research made it clear that inter-firm relations and agglomeration benefits were at play (Brusco 1982; Piore and Sabel 1984; Pyke and Sengenberger 1992).

The importance of firm clusters and inter-firm relations also became a significant factor in the studies of competitiveness at the industry and national level, headed by Michael Porter (Porter 1980; 1990). His approach, thus, sees clusters as an additional element in the competitive analysis integrated with firm and industry level factors. Emphasizing the potential impact of clusters on productivity growth, innovation, and new business formation (including foreign investment), Porter extends the competitive analysis in both directions: towards the meso and macro-levels with respect to cluster development policy initiatives, and towards the micro and firm-strategic perspective with respect to the competitive imperatives of both cluster formation and participation. Ultimately, while Porter lays a theoretical foundation under his recommendations based on the effects of competition and cooperation on competitiveness, it is perhaps not surprising that many of the recommendations, particularly at the firm level, are in fact formulations of not only his own empirical findings but also those of development studies researchers. 


\section{A theoretical probe into the borderland of Business Studies and Development Studies}

\section{c. Development studies}

The interest for inter-firm relations in development studies grows out of the interest in industrialization within the modernization and economic planning tradition. Albert Hirschman introduced his concepts of backward and forward linkages out of concern for manufacturing firms not having high coefficients in the input-output matrix of developing economies (Hirschman 1958). The firm could not source inputs, neither was there a market for outputs. Thus, it became a concern for industrial policy and strategy to secure the growth of linkages within the domestic economy. Such linkages could be nurtured within industrial districts where firms related to each other were located. Besides introducing the agglomeration dimension, development policy also focused on SMEs, as the main type of firms to be located in the assigned industrial districts were mainly newly established enterprises.

Combining the potential of firm external economies with that of joint action between firms, clusters were thus seen as a fortifying environment for developing country firms, whether in their pursuit of local markets or as a bulwark against international competitive pressures. In particular, both external economies and the facilitation of joint action were and are seen to serve an essential role in overcoming some of the many market and institution failures, characteristic of many developing economies. Benefits from firm agglomerations and networks do, however, not accrue automatically but depend, among other factors, on firm management, which has proven vital for inter-firm learning and upgrading in network formations (Bessant et al., 2003).

The original debate on industrial districts and SME development was rather policy driven in the sense that it focused on policy instruments and implementation, rather than providing a better theoretically based understanding of the firm and firm-driven agglomeration processes in developing countries. More recently, the firm-based perspective has been (re)introduced via the debate on industrial clusters in Europe and the success stories from Italy being based mainly on medium and small size firms (Schmitz and Nadvi 1999). Within development studies the inspiration was strengthened by the continued interest for small scale enterprises (Pedersen 1994 et alt.; Rasmussen et alt. 1992; Schmitz 1989; Schmitz and Nadvi 1999). On that basis, research looking for agglomeration of successful clusters of firms in developing countries took off and gave rise to a rich cluster literature in development studies in the 1990s (Humphrey and Schmitz 1996; Schmitz 1995; Nadvi 1997). According to this literature, the cluster agglomerations found in developing countries were rarely grown out of a planned industrial district design but had much more to do with a traditional interest, particularly for craft based firms, to locate close to each other and benefit from externalities. The perspective was very much that of the small firm and how it could overcome the barriers of smallness. At the policy level, this literature spurred an interest - not least international organizations participated in the debate in order to identify practical means that could strengthen SME development (UNIDO 1997; UNCTAD 1998).

\section{d. Issues of convergence}

Thus, the interest for industrial clusters in business and development studies converged during the 1990s. Conceptual tools were shared and a common body of literature developed.

The interest for firm clusters in connection with analysis of industry and national competitiveness in the Porter tradition in developed countries had spillovers in the sense that studies of competitiveness were also made for developing countries, but it did not lead to new theoretical and conceptual developments of a similar nature to those emerging from the above cluster research tradition. 


\section{Firms in developing countries}

An important challenge to the cluster research, and particularly to the strategic and policy implications of this research, came from the internationalization perspective that was not always well accommodated within the framework: Economic internationalization and integration gave/meant increased implications for the strategies of firms located in clusters and the changes in economic organization with the rise of outsourcing and globalization of the value chain. Challenges of firms in clusters located in developing countries of internationalizing and becoming integrated in the global economy is accommodated in the literature on global commodity chains, global value chains and global production networks that is mainly but not exclusively found in the development studies literature (Bair 2005; Nadvi 1999; Nadvi and Halder 2005). The aspects of the internationalization of developing country firms are taken up in the following section.

\section{Firm internationalization}

In this section, we will examine three aspects of the firm internationalization debate evident in the fields of business and development studies: internationalization of local firms in developing countries, global value chains, and foreign direct investment.

\section{a. Internationalization of developing country firms}

Historically, development studies and business studies have been interested in the internationalization of developing country firms (DCFs) for very different reasons.

\section{Development studies}

Within development studies, the recognition of the limitations of inward-oriented, importsubstituting development strategies largely shifted the focus to outward-oriented macro and meso-level recommendations in relation to development and industrialization policy. Within this context, to the extent that the micro-level internationalization strategies of individual firms were considered, the primary areas of attention tended to revolve around export facilitation and how firms got access to foreign partners and became integrated in the global economy. Here, different frameworks have come into play either focusing on local firm linkages with foreign MNCs as a result of FDI, integration via global value chains (GVCs), and/or potential integration in the global production network (GPN) (Henderson et al., 2002; Yeung et al., 2006). Often the agency of the individual developing country firm was of secondary concern relative to that of other more powerful actors, be it the state or developed country MNCs. However, two inter-related perspectives of economic internationalization have a rich representation in development studies. One is the more prescriptive interest in how SMEs rather than conglomerates or developing country MNCs can initiate export production and overcome entry barriers to export markets. The other includes more survey-type studies of how developing country firms are challenged by increased international competition often emerging from trade policy reforms and of their competitive responses (Kaplinsky and Morris,1999). This literature is particularly rich for firms located in middle income developing countries with a relative large organized business sector like Malaysia, South Africa and Brazil

\section{Business studies}

Drawing on and applying a range of theories essentially derived from a developed context, business studies, on the other hand, has historically been interested in the specificities encountered as DCFs enter other developing or even developed economies. The focus here has above all been one of agency, including the resulting implications of any such specificities 


\section{A theoretical probe into the borderland of Business Studies and Development Studies}

for firm strategy. Given this agency-centric firm-strategic perspective, business studies has tended to focus on those firms that have the resources and capabilities to internationalize relatively directly rather than via the 'embedded' or indirect internationalization, which has been more focused of within development studies.

Recently, there has been a growing focus on the internationalization of developing country firms ${ }^{20}$ and it has been stressed how DCFs can embark on outward oriented strategies either by exporting or by linking up to MNCs and global value chains (Kuada, 2004). These strategies can either be 'inward' internationalization (linking up to MNCs located in the host economy) or 'outward' internationalization (linking up to global value chains). Such internationalization strategies face serious constraints, including trade barriers in the North, lack of supportive regulation, and MNC strategies that are reluctant to move advanced functions to developing countries. In this sense, if the bias of development studies' research of firm-level has been towards the SME, that of business studies has been more towards the MNC, originally in relation to developed country FDI and more recently with respect to the foreign expansion of DCMNCs.

One of the main obstacles for DCFs is the widespread presence of failures in the markets for technology and knowledge. This traditionally has made it very difficult for DCFs to access the technology and know-how needed for upgrading. More recently, inspired by transaction cost economics, Teece and others have argued that DCFs can increasingly access complementary assets such as distribution systems and know-how due to the relatively open intermediary product and technology markets of many OECD countries (Teece 2000). This ability to buy existing and proven technologies and adapt them to local conditions has sometimes been referred to as 'the advantage of backwardness' (Gerchenkron, 1962). Moreover, Teece argues that developing country firms may have an advantage vis-à-vis Northern firms in that they are less likely to be limited by path dependencies and institutional sclerosis and may therefore more effectively and rapidly embark on promising strategic paths (Teece 2000).

\section{Issues of convergence}

Third world MNCs: Third world MNCs is an example, where we need to understand the particular location context of these companies in order to understand their global strategy (Beausang, 2003; Ramamurti, 2004). For instance, it has been noted that Third World MNCs typically are investing backward in the Investment Development Path (IDP), because their business models are particularly suited to less developed country conditions (Dunning and Narula, 1996). Moreover, it has been pointed out that many TWMNCs are part of large business groups rather than stand alone firms (Khanna and Palepu, 1997) or are more or less state owned companies, used as a tool for foreign policy (UNCTAD, 2006).

Outsourcing: Another internationalization mode of developing country firms is linking up to foreign firms in outsourcing relationships. Here the discussion within development studies

\footnotetext{
${ }^{20}$ International marketing research has also shown specific interest in issues related to emerging economies, see Advances in International Marketing, special issue 10, 2000.
} 


\section{Firms in developing countries}

evolves around whether developing country firms are actually able to move into higher value added activities such as R\&D or marketing and distribution, or whether they will be stuck with low value added activities (Mudambi, 2007). This discussion could be informed by resource based theories of firm strategy that suggests that the space for firms in developing countries may be larger than what the macro and meso-level theories on outsourcing and development tend to suggest (Pottenger, Hansen and Schaumburg-Muller, 2007).

\section{b. Global value chains}

The notion of value chains plays a prominent role both within development studies and business studies. The value chain metaphor is a way of analytically moving beyond the level of individual firms and industries, to look across firm and industry boundaries. The global value chain thinking is simply about the value chain organized across borders. The value chain thinking has moved toward the center of both streams of literature, however, the understanding of the concept differs wildly.

\section{Business studies}

Within business studies, Porter has led the way with his value chain thinking. Competitiveness is not, he argues, a firm specific concept but is rather closely related to the concept of 'value system'. This concept is used to describe the stream of value-added activities within an industry; that is, outputs from value-added activities of one company feed as inputs into another company in a sequential downstream process of economic value creation. The basic tenet in the value system's management is 'operational alignment'. This means the input flows must be coordinated in a manner that ensures timely, reliable and costeffective flows of appropriate quantities and quality of inputs to other chain members. Seen from this perspective, competition within industries tends to exist between value chains rather than between companies (Hansen and Kuada, 2006). Porter (1986) showed how the value system increasingly is organized across borders. In other words, firms slice up their value chains and source more and more advanced functions globally with a view of gaining competitive advantage. Many MNCs are moving from having dispersed value chains, with more or less complete value chain integration, toward concentrated value chains, where individual locations serve a specialized and unique role in the firm's global value chain. Outsourcing is a consequence of firms increasingly externalizing functions that are non-core to the company (Prahalad and Hamel, 1990). Outsourcing to developing countries are typically undertaken to gain factor cost advantages (mainly cheap labor) but also to access more advanced human skills, as seen within outsourcing of administrative and $R \& D$ functions.

\section{Development studies}

In the early 1990s, Gereffi, parallel with and partly inspired by Porter, introduced the notion of 'Global Commodity Chains' (Gereffi et al, 1994), which later was modified and renamed 'Global Value Chains' (GVC) (Humphrey and Schmitz, 2001). The idea is that the world economy to a large extent is configured by vertically organized value chains encompassing countries in the North and the South. As in Porter's value chain thinking, a given value chain activity can be organized across borders. However, there are important differences between Porter's and Gereffi, Humphrey and Schmitz's value chain thinking: while the unit of analysis for Porter, in his strategic models, is the intra-firm value chain, the value chain in the GVC literature is elevated to the unit analysis, independent of any particular firm but emphasizing inter-firm linkages and chain governance (Kaplinsky and Morris, 2001). A more important difference is that the GVC literature strives less to analyze, how firms build competitive 
advantage through optimizing their value chains, and more to examine how the configuration of global value chains are instrumental in shaping a global division of labor between the North and the South. According to this view, lead-firms are organizing and setting the terms of these chains, sometimes being buyers (such as retailers), sometimes being producers (such as auto or electronics producers). The GVC literature has made a significant contribution to the understanding and characterization of cross-bordering inter-firm relations, their governance, and opportunities for developing country firm up-grading ${ }^{21}$. Originally, the global value chain thinking left little opportunity for upgrading of local firms in developing countries, however, later the perspective was refined to include governance modes (market, modular, relational, captive and hierarchy), where certain types actually opened options for upgrading and to include various types of upgrading (product, process, functional and value chain), where certain types of upgrading were more likely than others. Most recently, the research on the possibilities for upgrading has been occupied with the barriers made by international public and private standards and conventions on the exporting supplier from developing countries (Gibbon and Ponte, 2005) ${ }^{22}$.

\section{Issues of convergence}

Interfirm dynamics in GVCs: In the more recent GVC writing, growing attention has been devoted to micro perspectives. The literature has increasingly moved toward the firm perspective in order to understand the international division of labor/configuration of global value chains (see e.g. Gereffi et al., 2005). Concepts and theories borrowed from business economics are brought in to understand the inter-firm relations in global value chains, e.g. transaction cost economics, network based, and resource based perspectives. The GVC scholars have also more directly discussed the strategic space for developing country firms being linked to the global economy through GVCs (see e.g. Gereffi, Humphrey and Sturgeon, 2005; Schmitz, 2004).

Transport services and global value chains: A potential gap in the development literature on GVCs concerns the role of the transport industry in binding together global value chains. This issue could be informed by insights of business studies - what is the interrelation between

\footnotetext{
${ }^{21}$ Through global chains, patterns of industrial production and organization are extending to the South, in particular to those countries with export-oriented development strategies (Gereffi et al., 1994). An international division of labor is organized by dominant firms in chains sending signals of cost-efficiency through the chain. In buyer-driven chains, dominant buyers demand that their merchandise producers should lower prices. This reinforces the pressure on their contractors down the chain to lower prices of inputs and components supplied. This may necessitate lower wages for employees and the adoption of other cost-cutting strategies within individual firms. The decision of some producers of footwear, garment and consumer electronics to locate their production units in countries with cheap but skilled labor can partly be explained with the systemic effects of cost-cutting pressure initiated by chain drivers.

${ }^{22}$ The global production networks literature which has been written largely by economic geographers, has grown in parallel to the GCV research but along the same lines, looking at how integration into global production takes place. A main difference is that the global production network literature puts more emphasis on location and relational aspects than on governance issues (Henderson et al., 2002).
} 


\section{Firms in developing countries}

strategies of MNCs in the transport sector and the integration of developing country firms into global value chains? (Greve, Hansen and Schaumburg Muller 2007).

GVCs for social and environmental development: Another issue of convergence is related to the observation that global value chain dynamics may be powerful drivers of the export of social preferences, e.g. the environmental or CSR standards from the North to the South (von Moltke, 1998; Altenburg, 2004).

\section{c. MNCs and foreign direct investment}

MNCs and the welfare implications of their foreign direct investment have always been at the heart of the literature on FDI and therefore there has been a close affiliation between development oriented and business oriented accounts, with the same authors crisscrossing between the two perspectives. Thus, this literature is possibly closer to convergence than any of the previous literatures discussed.

\section{A business perspective}

The FDI literature originates in a dissatisfaction with economics' (in-) ability to explain, why firms undertake FDI. It was felt that FDI cannot be satisfactorily explained as a portfolio investment or as a capital arbitrage in the face of varying interest rates in different markets. Hymer's seminal PhD thesis from the early sixties opened the discussion by pointing out, how FDI should be seen as a consequence of MNCs' attempts to extend and exploit their dominant market positions. The market power perspective was subsequently criticized from a transaction cost perspective holding that FDI is an internalization of cross-border market exchange with high transaction costs. FDI has also been understood as a learning process (Johanson and Vahlne 1977), as a consequence of asset augmenting strategies (Dunning, 2000), or as attempts to leverage knowledge resources across borders (Grant et al., 2000). Moreover, from asking questions related to why FDI takes place and why MNCs exist, questions are increasingly related to how MNCs can balance internalization and externalization in optimal ways, or how they can gain competitive advantage through internationalization, etc. (Dunning, 2000; Buckley, 2004). A subsection of the FDI literature has looked into MNC strategy in emerging markets, arguing that such markets require different analytical tools in terms of marketing (Arnold and Quelch, 1998), in terms of entry modes (Meyer and Estrin, 2000), and in terms of understanding the particular formal and informal institutions of developing countries (Wright et al., 2005).

\section{A development perspective}

As mentioned, the welfare and thereby development implications of FDI has always been at the heart of the FDI literature. Hymer was concerned that MNCs would extent exploitive practices to developing countries (Hymer, 1976) and soon emerged a heated debate on whether MNCs should be understood in terms of competition suppressing practices (i.e. sources of market failures) (see e.g. Caves, 1996), or rather should be understood as organizations introduced efficiently in markets that due to high transaction costs could not deliver (Rugman, 1981). A huge literature on the development implications of FDI exists (see 
e.g. UNCTAD, 1999 for an overview of the issues and Meyer 2004 for an overview of the research). ${ }^{23}$ Although it appears that the development perspective has been inadequately covered in the FDI literature in recent years, a revitalization has evidently taken place under the heading of 'spillovers' (Blomstrøm and Kokko, 2000; Meyer, 2004, Scott Kennel and Endevick, 2005). The question posed by this perspective is, to what extent the skills and advantages of MNCs diffuse to local firms and the country at large. Such spillovers can be demonstration effects or it can be competition effects (Blomstrøm and Kokko, 2000). In relation to this, particular interest has been given to firm linkages and transfer of knowledge and technology from MNCs in various studies of specific host countries. Through linkages to local suppliers and distributors, MNC practices disseminate to local firms, and it is argued that substantial knowledge and technology may be transferred from the MNC to its local partners, especially when it is considered non-propriety. However, the studies also show a dependency of effects on host country institutions and policies (Hansen and SchaumburgMüller, 2006; Jomo et al., 1999; Rasiah, 2004).

\section{Issues of convergence}

Internalization and spillovers: In regard to spillovers, there is an interesting difference between the two fields' understandings of this concept that may spur interesting theoretical and conceptual development. On the one hand, the business perspective points out that the very purpose of FDI is to avoid that proprietary knowledge, technology or competencies are diffused to competitors in the host country. Thus, MNCs will do what they can to prevent spillovers from happening. On the other hand, development studies points out that FDI should be attracted, in large part due to the huge potential spillovers on local firms. But for spillovers to happen, it is required that MNCs fail to fully internalize. The relation between the degree of internalization and the degree of spillovers seems to be an area where the two fields can benefit from greater dialogue.

Bottom of the pyramid: The recent writings on 'bottom of the pyramid' firm strategies are another area, where there is great potential for convergence of business studies and development studies. Bottom of the Pyramid strategies are essentially a pledge for MNCs to internalize developmental preferences in their strategies in order to be more profitable (Phrahalad, 2002; Hart and London, 2004).

MNCs and competitiveness: One of the key questions of convergence could be related to the interaction between MNC strategies and the competitiveness of locations. Thus, it is realized that competitiveness of locations is increasingly determined by the inflow of FDI, but also that foreign investors increasingly seek out locations that display strong competitiveness in order to access assets such as clusters of dynamic firms and industries and world-class resources (Dunning, 1996). This circular relationship between business strategy and government strategy calls for integrated perspectives. The interaction between the macro-

\footnotetext{
${ }^{23}$ Meyer (2004) reviews the literature on development effects of FDI: The literature is assessed on five dimensions: local firms, the social context, local institutions, the natural environment and the macro economy (2004). Based on this review, Meyer makes a plea for more research on how developing countries are affected by FDI.
} 


\section{Firms in developing countries}

economic environment and FDI is also explicitly discussed in the Investment Development Path (IDP) literature (see e.g. Dunning and Naruallu, 1996), where it is pointed out that particular MNCs are attracted to particular types of location advantages, and where the particularities of the MNCs investing in turn determine and shape the movement of the country in question along the IDP (Dunning and Narula, 1996; Scott-Kennel and Endevick, 2005).

\section{Conclusions and perspectives}

In this paper we have reviewed business studies' and development studies' approaches to the same phenomena, namely firms in developing countries. We went through a number of themes where there is potential for convergence or at least, for mutual inspiration. Two observations should be highlighted:

First, we can evidently see that, both within business studies and development studies, there is a growing interest in understanding firms in developing countries, and within both fields we have seen a profound surge in research on firms in developing countries in recent years. This is both in relation to institutional aspects of firm activity in developing countries, the role of clusters and entrepreneurs, and, of course with globalization, internationalization processes of local firms, MNCs and value chains.

Second, our impression is that these developments in the two fields largely have taken place in a parallel rather than an integrated manner. It appears that the two fields have not been able to communicate and inspire each other adequately, and, thus, have failed to effectively address empirical phenomena that fall squarely in the borderland of the two fields. We speculate that career paths, departmental divisions of labor, dynamics of disciplinary specialization with authors publishing in different journals and attending different conferences, have all contributed to a lack of cross-fertilization between the two fields. This lack of conversation may be as it is, was it not for the fact that with globalization of economic activity, the sharp division between the two fields becomes increasingly counter-productive. With globalization, we argued, the distinction between developmental and firm strategic perspectives becomes increasingly blurred, partly because firms increasingly are seen as carriers of key development inputs, partly because development strategies and objectives increasingly become internalized in firm strategy. Thus, we emphasized that there is a pertinent need for better integration of the two fields, with a view to improving the analysis and prescriptions of both. This we showed in relation to the debate on markets and institutions, where we argued that both the notion of market failures and the notion of institutions provide common ground for the two literatures, especially in relation to the analysis of MNCs in developing countries. In relation to clusters and entrepreneurship we argued that while the business literature seems mainly occupied with the institutional differences from the mainstream Anglo-Saxon context, it nevertheless points at two important aspects that deserve more research to understand strategic options for developing country firms - norms of firm rivalry and their implications for competitive dynamics, and network type strategies and their effectiveness of the different strategies found in different economies. More generally, business studies should, given the institutional differences, go more into exploring firm internal learning and development of management capabilities to address important issues of organisation, HRM etc. Finally, on the issue of internationalization, we found that interests are converging around LDC firm strategy, global value chains and MNCs and that, in fact, growing dialogue is identifiable. 


\section{A theoretical probe into the borderland of Business Studies and Development Studies}

In this paper, we have mainly scanned the theoretical literature to identify themes and dimensions, where the interests of the two fields are converging. A next step in our search for business and development studies will be to review the empirical research on firms in developing countries to find examples where there is evidence of an integrated perspective contributing fruitfully to knowledge formation within both fields.

\begin{tabular}{|c|c|c|c|}
\hline & Busines studles & Development studles & Issues of convergence \\
\hline \multirow[t]{2}{*}{$\begin{array}{l}\text { Markets } \\
\text { and } \\
\text { Institutions }\end{array}$} & $\begin{array}{l}\text { Market failures explain the } \\
\text { existance of firms (Coase) }\end{array}$ & $\begin{array}{l}\text { Market failures explain lack } \\
\text { of development and welfare } \\
\text { loss (Lall) }\end{array}$ & $\begin{array}{l}\text { Welfare effects of different types of } \\
\text { fims, e.g. conglomorates and MNACs } \\
\text { (TCE versus market power view) }\end{array}$ \\
\hline & $\begin{array}{l}\text { Firms are institutions to } \\
\text { circumvent deficient markets } \\
\text { (Williamson) and effectively } \\
\text { transfer knowledge (Kogut } \\
\text { and Zander) }\end{array}$ & $\begin{array}{l}\text { Institutions are key pre- } \\
\text { requisites for development } \\
\text { (North, Stiglit) }\end{array}$ & $\begin{array}{l}\text { Internalizing institutions in strategy } \\
\text { thinking (Peng'Meyer) } \\
\text { Private sector development strategy } \\
\text { findustriaization strategy and firm } \\
\text { strategy (Gibbon) }\end{array}$ \\
\hline $\begin{array}{l}\text { Entreprene } \\
\text { urship }\end{array}$ & $\begin{array}{l}\text { Neo-Schumpeterian theories } \\
\text { of the firm }\end{array}$ & SME policy focus & $\begin{array}{l}\text { SME and entrepreneurs hip common } \\
\text { tools }\end{array}$ \\
\hline Clusters & $\begin{array}{l}\text { Outsourcing and survival of } \\
\text { clusters }\end{array}$ & $\begin{array}{l}\text { Clusters integration in global } \\
\text { economy }\end{array}$ & $\begin{array}{l}\text { Common approach with economic } \\
\text { geographers; } \\
\text { I5stes related to globalisation }\end{array}$ \\
\hline \multirow[t]{3}{*}{$\begin{array}{l}\text { Firm } \\
\text { intermational } \\
\text { ization }\end{array}$} & $\begin{array}{l}\text { Outward and inward } \\
\text { internationalization of } \\
\text { developing country firms } \\
\text { (Kuada) }\end{array}$ & $\begin{array}{l}\text { Export promotion } \\
\text { Linkage promotion } \\
\text { (Altenburg) }\end{array}$ & $\begin{array}{l}\text { Linkages and economic deve lopment } \\
\text { (Scott Kennel and Giroud)) } \\
\text { Global value chain integration and } \\
\text { economic development }\end{array}$ \\
\hline & $\begin{array}{l}\text { Global value chain } \\
\text { configuration (Porter) }\end{array}$ & $\begin{array}{l}\text { Global value chains and the } \\
\text { global division of labor } \\
\text { (Gerefi) }\end{array}$ & $\begin{array}{l}\text { Interfirm relations in global value chains } \\
\text { (Gerefi et al 2005) } \\
\text { Using value chai n dynamics to promote } \\
\text { development (Altenburg) }\end{array}$ \\
\hline & $\begin{array}{l}\text { MNCstrategy in developing } \\
\text { countries (Dunning) }\end{array}$ & $\begin{array}{l}\text { Development effects of FDl } \\
\text { (Lall) } \\
\text { CSR (Jenkins) }\end{array}$ & $\begin{array}{l}\text { The unique advantages of TWMNCs } \\
\text { (Beausang) } \\
\text { Spill overs and firm strategy (Forsgren) } \\
\text { Bottom of the pyramid (Phrahalad) }\end{array}$ \\
\hline
\end{tabular}




\section{Firms in developing countries}

\section{References}

Altenburg, T. \& Meyer-Stamer, J. (1999) How to Promote Clusters: Policy Experience from Latin America, World Development, 27:9, pp. 1693-1713

Altenburg, T. and C. von Drachenfels (2006), "The "New Minimalist Approach" to Private-Sector Development: A Critical Assessment”, Development Policy Review Vol. 24 (4), pp. 387-411

Altenburg, T.; Cooperating with the private sector in development cooperation: Strategic alliances with lead firms in production networks. Paper presented at the Annual Conference of the Verein für Socialpolitik, Ausschuss für Entwicklungsländerforschung, Cologne, 2-3 July, 2004.

Altenburg, Tilman, 'Linkages and Spill overs between TNCs and SMEs in developing countries', in UNCTAD, TNC-SME linkages for development, UNCTAD: Geneva, 2000

Arnold, D., and Quelch, "New strategies in emerging markets", $\underline{\text { Sloan }}$ Management Review, Vol 40 no 1, Fall 1998

Bair, Jennifer (2005) Global Capitalism and Commodity Chains: Looking Back, Going Forward; Competition and Change 9(2)

Bates, R. ed. and co-author (1988). Toward A Political Economy of Development: A Rational Choice Perspective. Berkeley: University of California Press, Series in Social Choice and Political Economy.

Beausang, F., "The theory of the developed country MNE and the Third world MNE”, in Beausang, F., Engine of competitiveness or new form of dependency?, London: Palgrave, 2003

Bessant, John, Raphael and Mike Morris (2003). "Developing capabilities through learning networks", International Journal of Technology Management and Sustainable Development, 2:1, pp. 19-38.

Bhagwati, Jagdish N. Directly Unproductive, Profit-Seeking (DUP) Activities, The Journal of Political Economy, Vol. 90, No. 5 (Oct., 1982), pp. 988-1002

Bhagwati, J.N. \& T.N. Srinivasan (1999), 'Outward orientation and development: are revisionists right?’, Discussion Paper No. 806, Economic Growth Centre, Yale University, New Haven

Biggs, Tyler, Is small beautiful and worthy of subsidy, World Bank/IFC Discussion Paper, pp 1-31

Blomström, M. \& A. Kokko (2000). Multinational corporations and spill overs, in Blomstrøm M., A. Kokko and M. Zejan. Foreign direct investment: Firm and host country strategies. London: Palgrave Macmillan.

Brouthers,K.D., and Nakos, G. (2004). SME entry mode choice and performance: A transaction cost perspective. Entrepreneurship, theory and practice, 28 (3) 229-247.

Buckley and Casson, The future of the multinational enterprise. London: Macmillan, 1976.

Buckley, P. (2002) 'Is the international business research agenda running out of steam?', Journal of International Business Studies 33: 365-373.

Buckley, P. and P. Ghauri, "Globalization, economic geography and the strategy of MNEs”, in Journal of International Business Studies, Vol 35, 2004, pp 81-98 
Caves, R.; Multinational firms and economic analysis. Cambridge: Cambridge University Press, 1996.

Chang, H., 'Globalization, TNCs and economic development: Can developing countries pursue strategic industrial policy in a globalizing world economy', in Baker et al., Globalization and progressive economic policy, Cambridge: Cambridge University Press, 1998

Chang, H.-J. (2002) Breaking the mould: an institutionalist political economy alternative to the neo-liberal theory of the market and the state, Cambridge Journal of Economics, 26, pp. 539-559

Coase, R.H.; The nature of the firm, in Economica, no 4, 1937

Dicken, P. (2004) Global Shift, London: Sage

Dunning, J. and Narula, R., "Industrial development, globalization and multinational enterprises: new realities for developing countries”, in Dunning J., and Narula, R., Multinationals and industrial competitiveness, Cheltenham, UK, 2004

Dunning, J., 'Some paradoxes of the emerging global economy', in Dunning, J., Alliance capitalism and global business, London: Routledge, 1997, pp 357-370.

Dunning, J., 'The eclectic paradigm of international production: A restatement and some possible extensions, Journal of International Business Studies, 19(1), 1988

Dunning, J.H. and Narula, R. (1996) The investment development path revisited: some emerging issues, in J. Dunning and R. Narula (eds), Foreign Direct Investment and Governments: Catalysts for Economic Restructuring, London: Routledg

Dunning, John (1996), 'Re-evaluating the benefits of foreign direct investment', in J. Dunning and R. Narula (eds), Foreign Direct Investment and Governments: Catalysts for Economic Restructuring, London: Routledge

Dunning, John H. (2000), "Globalization and the theory of MNE activity", in Hood and Young, Globalization of Multinational Enterprise Activity and Economic Development, Basingstoke: Hampshire, 2000. pp. 21-43

Enderwick, P. "Attracting desirable FDI: Theory and evidence", in Transnational Corporations, Vol 14, No 2, 2005, pp.93-120

Ernst, D. (2002) Global production networks and the changing geography of innovation systems. Implications for developing countries, Economics of Innovation and New Technology, 11:6, pp. 497-523

Esser, K. Wolfgang Hillebrand; Dirk Messner and Jörg Meyer-Stamer; Systemic competitiveness -new governance patterns for industrial development. London: Frank Cass, 1996.

Evans, D. et. al. (2006) Deep and Shallow Integration in Asia: Towards a Holistic Account, IDS Bulletin 37:1,

Forsgren, M., “Are multinational firms good or bad”, in Havila et al., Critical perspectives on internationalization London: Pergamon, 2002

Foss, N. (1996), "Strategy, economics and Michael Porter”, Journal of Management Studies, Vol. 33, pp. 1-24. 


\section{Firms in developing countries}

Gerchenkron, A. (1962). Economic backwardness in a historical perspective, Cambridge: Harward University Press.

Gereffi, G. and M. Korzeneiewicz (eds.); Commodity Chains and Global Capitalism. USA: Greenwood Press, 1994.

Gereffi, G., J. Humphrey, T. Sturgeon (2005) The Governance of Global Value Chains; Review of International Political Economy Vol. 11 (1), pp. 1-32.

Gibbon, p. and Stefano Ponte (2005) "The Rise of Buyer-Driven Value Chains in Africa” chap 4 in Trading Down - Africa, value chains, and the global economy Philadelphia: Temple University Press.

Giroud, A., and Scott-Kennel, J. (2006), 'Foreign-Local Linkages in International Business: A Review and Extension of the Literature', 2006 Academy of International Business Conference, Beijing, 23-26 June.

Görg H. \& Grenaway, D. (2002). Much ado about nothing? Do domestic firms really benefit from foreign direct investment? World Bank Research Observer, 19: 171-197.

Grant, R., et al., “Knowledge and the multinational enterprise”, in Millar, C. et al, International business: Emerging issues and merging markets, London: Macmillan, 2000

Greve, M., Hansen, M., Schaumburg Muller, H. (2007) Containershipping and Economic Development: A Case study of A.P.Moller-Maersk, CPH: CBS Press.

Hamilton, G. (ed) (1991). Business Networks and Economic Development in East and South East Asia. Hong Kong: University of Hong Kong Press.

Hansen, M.W., and Kuada, J., (2006) Theories of linkages, in Hansen, M.W. \& Schaumburg-Müller, H. (Eds.) (2006). Transnational Corporations and Local Firms in Developing Countries - Linkages and Upgrading, Copenhagen: Copenhagen Business School Press.

Hansen, M.W. \& Schaumburg-Müller, H. (Eds.) (2006). Transnational Corporations and Local Firms in Developing Countries - Linkages and Upgrading, Copenhagen: Copenhagen Business School Press.

Henderson, Jeffrey; Peter Dicken; Martin Hess; Neil Coe and Henry WaiChuong Yeung (2002). 'Global production networks and the analysis of economic development'. Review of International Political Economy, 9:3, pp. 436-464.

Hennart,J-F., 'The transaction cost theory of the multinational enterprise', in Pitelis \& Sudgen (eds), The nature of the Transnational Firm, Routledge, $1991^{*}$

Hirschman, Albert (1958). The Strategy of Economic Development, New Haven: Yale University Press.

Hoskisson, R., Eden, L., Lau, C-M. and Wright, M. (2000). 'Strategy in emerging economies'. Academy of Management Journal, 43, 249-67.

Humphrey, J. and H. Schmitz (2001); Governance in Global Value Chains. IDS Bulletin, Vol. 32, pp. 19-29.

Hymer, S., The international operations of national firms: A study of direct foreign investment Cambridge: MIT Press, 1976.

Hymer, S.; The international operations of national firms: A study of direct foreign investment. Cambridge: MIT Press, 1976. 
Iqbal, F. and ShujiroUrata (2002) , 'Small Firm Dynamism in East Asia: An Introductory Overview’. Small Business Economics, 18:1-3, pp. 1-18.

Johanson, J. \& J.-E. Vahlne, The internationalization process of the firm', in Four Decades of Uppsala Business research, Sweden: 1998

Johnson, B. \& B.-Aa. Lundvall (2003) National Systems of innovation and Economic Development, in: Muchie, M. et. al. (eds) Putting Africa First. The Making of African Innovations Systems, Aalborg: Aalborg University Press

Jomo, K.S., Greg Felker and Rajah Rasiah (eds.) (1999), Industrial Technology Development in Malaysia - Industry and firm studies, London: Routledge.

Kanbur, Ravi. 2002. “Economics, Social Science and Development.” World Development, Vol. 30, No.3, pp 477-486.

Kaplinsky, R. and Mike Morris. (2001). “A Handbook for Value Chain Research”. Report prepared for IDRC.

Kaplinsky, R. and Mike Morris (1999). "Trade Policy Reform and the Competitive Response in Kwazulu Natal Province, South Africa”, World Development 27:4, pp. 717-737.

Khanna, T. and Palepu, K. (1997). 'Why focused strategies may be wrong for emerging markets'. Harvard Business Review, 75, July-August, 3-10.

Khanna, T. and Palepu, K. (2000). 'The future of business groups in emerging markets: long-run evidence from Chile'. Academy of Management Journal, 43, 268-85.

Kogut, B. and Udo Zander, "Knowledge of the firm and the evolutionary theory of the multinational corporation", in Journal of international business studies, November 2003, Volume 34, Number 6, pp 516-530

Kuada, John, "Internationalization of firms from developing countries: Towards an integrated conceptual framework", Paper presented to conference on Globalization, internationalization of companies and cross cultural management, Ålborg, 27-29 October, 2004

Lall, S. FDI and Development: Policy and research issues in the emerging context, Queen Elizabeth House, University of Oxford, QEH Working Paper Series - QEHWPS43, 2000

Lall, S.; Developing Country Firms in the World Economy: Governance and Upgrading in Global Value Chains, INEF Report 61, Duisburg, 2002b

Lall, S.; FDI and Development: Research issues in the merging context, in B. Bora, Foreign direct investment: research issues. London: Routledge, pp. 168-191, 2002.

Lau, Chuong-Ming (2002). 'Asian Management Rsearch: Frontiers and Challenges’ Asia Pacific Journal of Management, 19, pp. 171-178.

Liedholm (2002), Small Firm Dynamics: Evidence from Africa and Latin America; Small Business Economics, 18, pp. 227-242

London, T. and Hart, S. L. (2004). 'Reinventing strategies for emerging markets: beyond the transnational model'. Journal of International Business Studies, 35, 350-70.

Lundvall, B.Å.; Why Study National Systems and National Styles of Innovation, Technology Analysis \& Strategic Management, Vol. 10, Iss. 4, pp. 407-421, 1998. 


\section{Firms in developing countries}

Lynn, S.R. Economic Development: Theory and Practice for a Divided World. Prentice Hall/Pearson Education, Upper Saddle River, New Jersey, 2002.

Martinussen, J.D. (1999): "Development Studies as a Subject Area” chapter 1 in Society, State and Market,

Meyer, K. (2004). Perspectives on Multinational Enterprises in Emerging Economies. Journal of International Business Studies, 35 (4), 259-276.

Meyer, Klaus and M.W. Peng (2005), "Probing theoretically into Central and Eastern Europe: transactions, resources, and institutions” Journal of International Business Studies 36, 600-621

Mintzberg, H. (1988). Opening up the definition of strategy, in Quinn, J.B., Mintxberg, H., and James, R.M. (eds.). The Strategy Process. Prentice Hall, Englewood Cliffs, pp.13-20.

Mudambi, R. Presentation to 40 years of International Business Conference, Reading, April 2007.

Nadvi, J. and G. Halder (2005). 'Local Clusters in Global Value Chains: Exploring Dynamic Linkages between Germany and Pakistan'. Entrepreneurship and Regional Development, 17, pp. 339-63.

Nadvi, K. \& S. Barrientos (2004) Industrial Clusters and Poverty Reduction, Ch. $3+4$ (pp. 9-28). Vienna: UNIDO. (19 p) (download from UNIDO: www.unido.org/publications/

Nadvi, K. (1998). 'The Cutting Edge: Collective Efficiency and International Competitiveness in Pakistan' Oxford Development Studies, 27:1, pp. 81107.

Narayanan, V.K. and Liam Fahey (2005). 'The Relevance of the Institutional Underpinning of Porter's Five Forces Framework to Emerging Economies: An Epistimological Analysis'. Journal of Management Studies,42:1, pp. 207-223.

Narula, R. and Dunning, J. (2000) 'Industrial development, globalisation and multinational enterprises: New realities for developing countries', Oxford Development Studies, 28: 141-167

Narula, R. and S. Lall (2004). Foreign direct investment and its role in economic development: Do we need a new agenda?. In The European Journal of Development Research; Understanding FDI assisted Economic Development Vol 16, no3, Autumn 2004.

Nelson, R.R. (ed.) (1993). National Systems of Innovation: A Comparative Study, Oxford: Oxford University Press.

North, D. C. (1990). Institutions, Institutional Change, and Economic Performance. Cambridge and New York: Cambridge University Press.

Peng, M., "Towards an Institution-Based View of Business Strategy" Asia Pacific Journal of Management, 19, 2002 251-267

Pieterse, J.N. (2001): “Trends in Development Theory” Chapter 1 in: Pieterse, J.N. Development Theory: Deconstructions/Reconstructions. London: Sage

Pietrobelli, C. \& R. Rabellotti (2005) Upgrading in Global Value Chains: Lessons from Latin America, in: Giuliani, E. et. al. (eds) Clusters Facing Competition: The Importance of External Linkages, Aldershot: Ashgate, 
Porter, M.E., 'Competition in Global Industries: A Conceptual Framework', in M.E. Porter (ed.), Competition in Global Industries, Harvard Business School, Cambridge, MA, USA, 1986.

Porter, Michael, "Building the Microeconomic Foundations of Prosperity: Findings form the Business Competitiveness Index", in: The Global Competitiveness Report, 2003-2004

Potenger, E., Hansen, M., Schaumburg Muller, H., Outsourcing for Development, CBDS Working Paper, CPH: CBS, 2007.

Prahalad, C. K. and G. Hamel (1990), The Core Competencies of the Corporation,' Harvard Business Review,May-June, 79-91.

Prahalad, C. K. and Hammond, A. (2002). 'Serving the world's poor, profitably’. Harvard BusinessReview, September, 48-57.

Prebisch, Raul. 1950. The Economic Development of Latin America and Its Principal Problems (New York: United Nations, Economic Commission for Latin America).

Ramamurti, Ravi (2004), Developing coungtries and MNEs: Extending and enriching the agenda, Journal of Business Studies 35, 277-83

Rasiah, Rajah (1999), “Malaysia’s national innovation system” in K.S. Jomo and Greg Felker (eds.) Technology, Competitiveness and the State, London: Routledge.

Rasiah, Rajah (2004), Foreign Firms, Technological Capabilities and Economic Performance - Evidence from Africa, Asia and Latin America, Cheltenham: Edward Elgar.

Rodrik, D. (2004) Industrial policy for the Twenty-First Century, (Download from http://www.ksg.harvard.edu/rodrik/)

Rugman, A.M., Inside the multinationals: The economics of internal markets, London: Croom Helm, 1981

Schmitz, H. (1999) Clustering and Industrialization: Introduction, World Development, 27:9, pp. 1503-1514

Schmitz, H. (ed.) (2004). Local Enterprises in the Global Economy - Issues of Governance and Upgrading. Cheltenham: Edward Elgar

Schulpen \& P. Gibbon (2002) Private Sector Development: Policies, Practices and Problems, World Development, 30:1

Schumpeter, Joseph (1955). The Theory of Economic Development. Harvard University Press: Cambridge, MA.

Scott-Kennel, J. and P. Enderwick, "FDI and interfirm linkages: exploring the black box of the IDP” in Transnational Corporations, Vol 14, no 1, 2005 pp. $105-130$

Stiglitz, J. (2003): “Towards a New Paradigm of Development” in J. Dunning (ed.) Making Globalization Good, Oxford: Oxford University Press

Teece, David, "Firm capabilities, and economic development: Implications for NIEs", in Kim and Nelson, Technology, learning and Innovation, Mass: Cambridge University Press, 2000, pp. 105-128.

UNCTAD (2006). World Investment Report 2006. Geneva: UNCTAD.

Viotti E.B. National Learning Systems - A new approach on technological change in late industrializing economies and evidences from the cases of 


\section{Firms in developing countries}

Brazil and South Korea. Technological Forecasting and Social Change, Volume 69, Number 7, September 2002, pp. 653-680(28).

Von Moltke (1998), Global Product chains: Northern Consumers, Southern Producers and sustainability. Environment and Trade no 15, Geneva: UNEP

Weiss, Linda, Globalization an the myth of the powerless state, Cambridge: Polity Press, 1998

White, Steven (2002). 'Rigor and Relevance in Asian Management Research: Where Are We and Where Can We Go?'. Asia Pacific Journal of Management. 19, pp. 287-352.

Whitley (2001). Developing Capitalisms: The Comparative Analysis of Emerging Business Systems in the South, in Jakobsen, G. \& J.E. Torp (eds) Understanding Business Systems in Developing Countries, New Delhi: Sage

Whitley, Richard: The development of management studies as a fragmented adhocracy. Social Science Information. Vol. 23 No. 4/5, s. 775-818, 1984

Williamson, O. E. (1975). Markets and Hierarchies. New York: Free Press.

Winter, S. G. (1964), 'Economic "Natural Selection” and the Theory of the Firm,' Yale Economic Essays, Vol. 4 (Spring). Department of Economics, Yale University: New Haven, pp. 225-72.[ISI]

Winter, S. G. (1964), 'Economic "Natural Selection” and the Theory of the Firm,' Yale Economic Essays, Vol. 4 (Spring). Department of Economics, Yale University: New Haven, pp. 225-72.[ISI]

Winter, S.G. (2009). 'Toward a neo-Schumpeterian theory of the firm'. Industrial and Corporate Change, 15:1, pp. 125-141.

World Bank (1993): The East Asian Miracle: Economic Growth and Public Policy, World Bank, Oxford University Press for the World Bank.

World Bank (2002): "Building Institutions: Complement, Innovate, Connect, and Compete” Chapter 1 in World Development Report 2002

Wright, M.; Filatotchev, I.; Hoskisson, R.; Peng, M.(2005)., "Strategy Research in Emerging Economies: Challenging the Conventional Wisdom”, Journal of Management Studies, Vol.42 (1), pp. 1-34. 